\title{
The challenges of droughts in selected rural communities in Saskatchewan
}

\author{
S. Kulshreshtha ${ }^{1}$, S. Abbasi ${ }^{1}$ \& E. Wheaton ${ }^{1,2}$ \\ ${ }^{1}$ University of Saskatchewan, Canada \\ ${ }^{2}$ Saskatchewan Research Council, Canada
}

\begin{abstract}
Periodic droughts are common phenomena in the semi-arid area of the Canadian prairies. Over the past 50 years there have been four major multi-year droughts in Saskatchewan, some of which were regional and even national in nature. The frequency and intensity of droughts is expected to increase in the future. One of the sectors most adversely affected by droughts is agricultural production (both crop and livestock production). Adaptation to these natural disasters is one way to cope. However, in this context, many questions need answering. These questions are addressed in this study using two communities in Saskatchewan that faced a drought during 2001 to 2003. Although droughts created adverse economic conditions, these were not the only cause of vulnerability of producers. In response to previous droughts, farmers had developed adaptation measures, such as adoption of minimum or zero tillage systems, off-farm employment, and participation in risk management programs of the federal government. In some cases, producers felt the inadequacy of risk-management programs as a major source of increased vulnerability from future droughts.
\end{abstract}

Keywords: droughts, Saskatchewan, impacts, adaptation, government policy.

\section{Introduction}

Droughts can inflict major adverse effects on agriculture, and through that on the producers and the local and regional economy. As a result of these impacts, producers are highly vulnerable - their income is greatly reduced, further creating other socio-economic impacts. However, producers do undertake adaptive measures in the face of such devastation. The main purpose of this study was to gain insights into the bio-physical and socio-economic vulnerabilities related to 
drought using a case study of two communities in Saskatchewan, Canada. In addition, adaptation measures selected (and adopted) by producers were also investigated.

\section{Study communities}

The two study communities were the towns of Kindersley and Maidstone, as well as their Rural Municipalities. The rationale for selection of the communities included drought frequency, population, and having a variety of sources of water supply. Kindersley is located in a part of Canadian prairies where droughts are frequent. Maidstone has a history of fewer droughts as it is farther north in a moister climatic region. The average rainfall for the most recent normal period (1981 to 2010) is $261.2 \mathrm{~mm}$ for Kindersley and $315.6 \mathrm{~mm}$ for Waseca (closest station to Maidstone). Normal annual snowfall amounts are $86.9 \mathrm{~cm}$ for Kindersley and about $100.8 \mathrm{~cm}$ for the Maidstone area [1]. Much of the moisture need for crop production is provided by snow-melt in the spring and rainfall in the crop growing-period.

Both communities are primarily agricultural, although Maidstone has some presence of oil and gas industry. Similar to the Maidstone area, the Kindersley area has exploitable deposits of natural gas and oil that contribute significantly to the area's economy. This industry provides secondary income source for many respondents in the Kindersley area. Both towns are small in size - Kindersley has a population of 4,678 in 2011, and Maidstone is even smaller with the 2011 population at 1,146 people $[1,2]$.

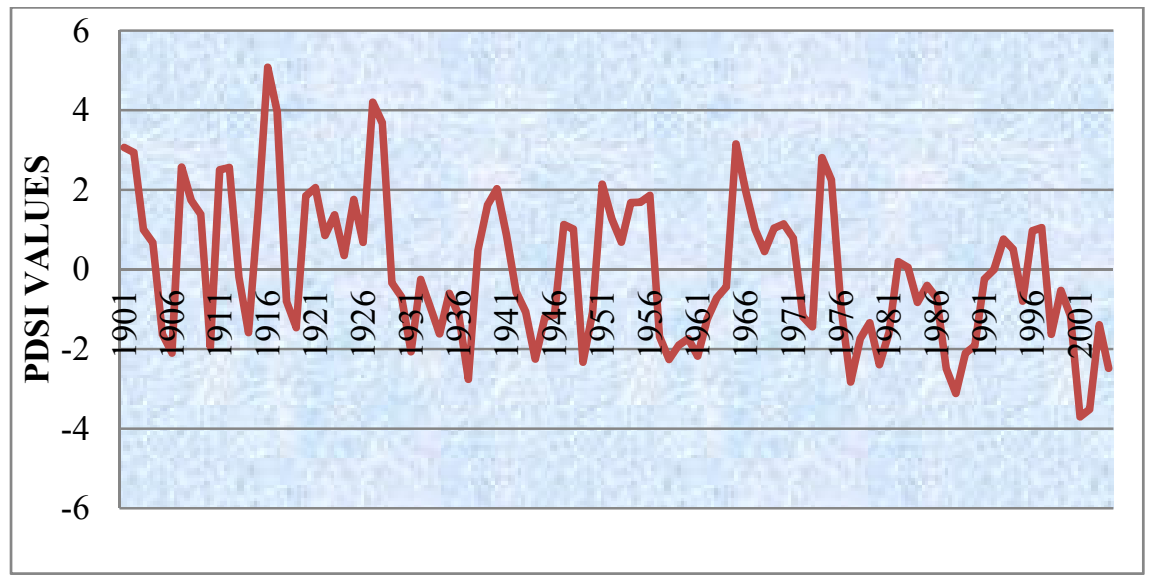

Figure 1: Drought patterns in Kindersley, 1901-2005.

\section{Drought characteristics in study communities}

Drought intensity for a given location can be estimated using value of Palmer Drought Severity Index (PDSI). An extreme drought condition prevails if the PDSI 
values are less than -4 . The spatial and temporal characteristics of drought in Kindersley and Maidstone communities were analyzed using PDSI calculated by [4]. From these, drought patterns were identified for the period of 1901-2005, including the top ten dry years, as well as characteristics of recent 2001-2003 drought and the comparison of the two study communities (Figures 2 and 3). On an annual basis, 2001 was ranked as the driest year in Kindersley with a PDSI value of -3.7 (Table 1).

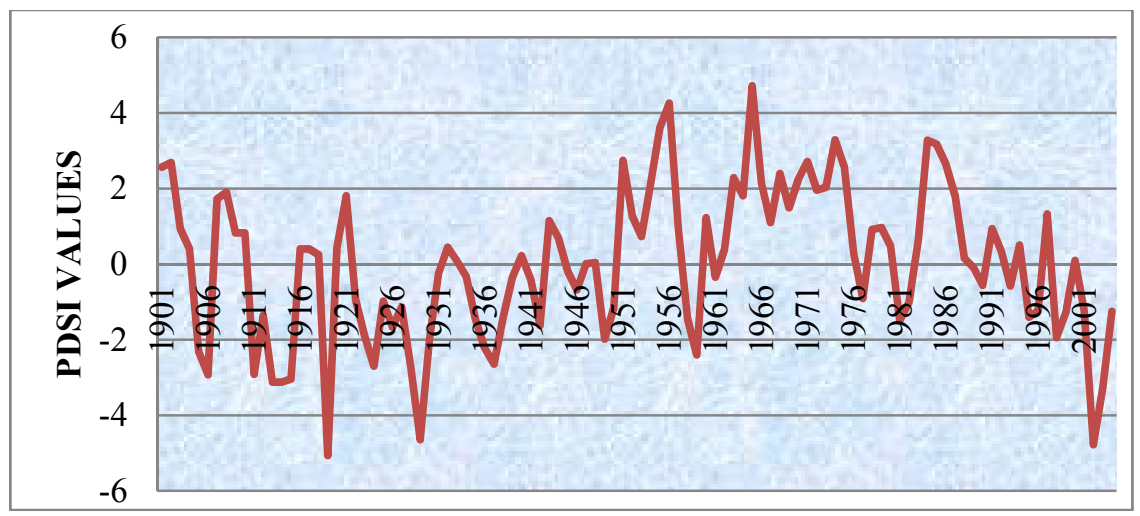

Figure 2: Drought patterns for Maidstone, 1901-2005.

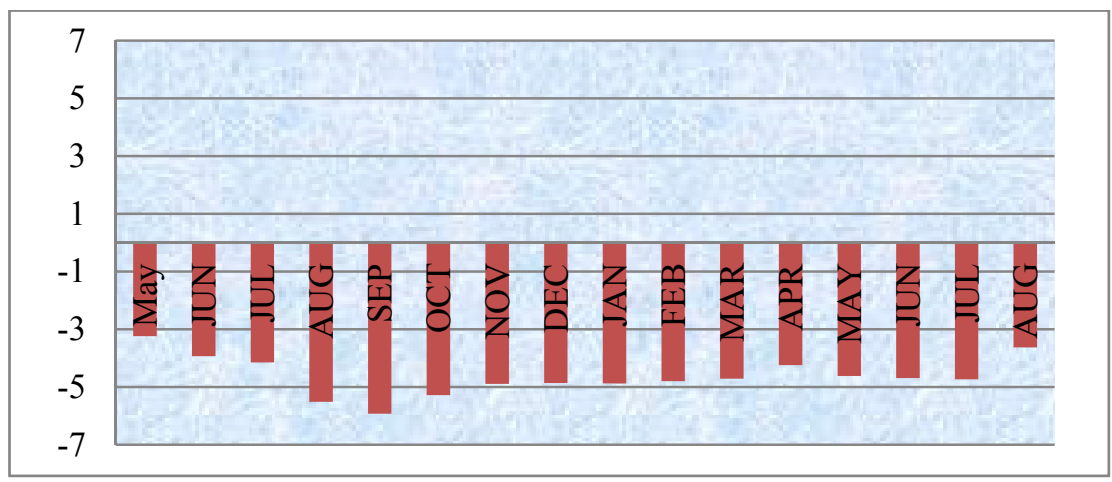

Figure 3: Crop growing PDSI value for Kindersley, May 2001 to August 2002.

During the period 1901-2005, Kindersley had three severe drought years, i.e. 2001, 2002 and 1988. The drought pattern and frequency in the relatively northern community of Maidstone were different from those experienced in Kindersley which is about $180 \mathrm{~km}$ farther south. Both 2002 and 2003 were severe droughts based on the PDSI values.

The crop growing period drought patterns were also examined. As shown in Figure 3, Kindersley was exceptionally dry in August and September of 2001, with a PDSI value of -5.4. The second driest growing period in Kindersley was in 2002. 
Table 1: Ranking of the ten driest years in study communities.

\begin{tabular}{|c|c|c|c|}
\hline \multicolumn{2}{|c|}{ Kindersley } & \multicolumn{2}{c|}{ Maidstone } \\
\hline Year & $\begin{array}{c}\text { Mean PDSI } \\
\text { Value }\end{array}$ & Year & $\begin{array}{c}\text { Mean PDSI } \\
\text { Value }\end{array}$ \\
\hline 2001 & -3.7 & 1919 & -5.0 \\
\hline 2002 & -3.5 & 2002 & -4.8 \\
\hline 1988 & -3.1 & 1918 & -3.2 \\
\hline 1977 & -2.8 & 2003 & -3.1 \\
\hline 1937 & -2.7 & 1914 & -3.1 \\
\hline 1987 & -2.4 & 1915 & -2.9 \\
\hline 2004 & -2.4 & 1906 & -2.8 \\
\hline 1980 & -2.3 & 1937 & -2.5 \\
\hline 1949 & -2.3 & 1928 & -2.2 \\
\hline 1958 & -2.2 & 1913 & -2.2 \\
\hline
\end{tabular}

Maidstone had several severe consecutive months of drought during August 2002-August 2003. The worst month was July 2002 with a PDSI below -6. In fact the entire growing season of 2002 was under severe drought conditions (Figure 4) [5].

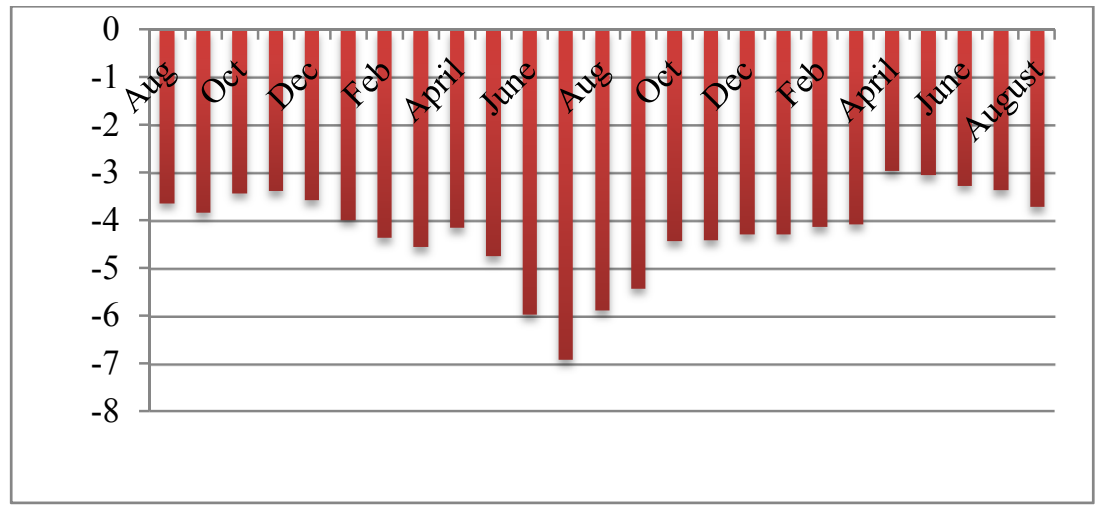

Figure 4: Crop growing PDSI value for Maidstone, August 2001 to August 2003.

A comparison of PDSI values for the two study communities illustrates the contrast in drought period, frequency, and severity. Based on the evidence presented above, it appears that Maidstone had a lengthy and severe drought during 2002 to 2003 compared to Kindersley. In contrast, Kindersley showed an earlier arrival of the drought. The period from May 2001 to June 2001 was a severe drought period in Kindersley. Wheaton et al. [6] also reported that during 20012002, the summer droughts extended much farther northward and both eastward 
and westward than the earlier major droughts in the region. This illustrates that fact that communities differ in timing and severity of droughts. For this reason, it is important to understand and characterize droughts at a local level, which may facilitate development and application of appropriate adaptation strategies.

\section{Impacts of droughts on communities}

\subsection{Effect on crops}

Agriculture productivity was strongly impacted by the 2001-2003 droughts. Both Maidstone and Kindersley faced crop yield losses as a result of these droughts. In the Kindersley area, in 2001 spring wheat, canola and lentil yields decreased to 54,51 and $41 \%$ of the historical average (1971-2000). The 2002 yields were even lower, at $34.3 \%$ for spring wheat, whereas canola crop was totally lost (Table 2). In Maidstone, 2001 had average-to-slightly-above-average crop yields; however the 2002 drought impacted yields of all major crops. The 2002 spring wheat yield was $70 \%$ of average (1971-2000) period (Table 3). The pea crop yield in 2002 also decreased to $23 \%$ of historical period yield.

Table 2: Impact of 2001-2003 droughts on agricultural yield in Kindersley (RM No. 290) [7].

\begin{tabular}{|c|c|c|c|c|c|c|}
\hline \multirow{2}{*}{ Year } & \multicolumn{2}{|c|}{ Spring Wheat } & \multicolumn{2}{|c|}{ Canola } & \multicolumn{2}{c|}{ Lentils $^{\mathbf{a}}$} \\
\cline { 2 - 7 } & $\begin{array}{c}\text { Yield } \\
\text { (bu/acre) }\end{array}$ & $\begin{array}{c}\text { \% of } \\
\text { Historical } \\
\text { Average }\end{array}$ & $\begin{array}{c}\text { Yield } \\
\text { (bu/acre) }\end{array}$ & $\begin{array}{c}\text { \% of } \\
\text { Historical } \\
\text { Average }\end{array}$ & $\begin{array}{c}\text { Yield } \\
\text { (lbs/acre) }\end{array}$ & $\begin{array}{c}\text { \% of } \\
\text { Historical } \\
\text { Average }\end{array}$ \\
\hline Historical $^{*}$ & 28.0 & & 17.0 & & $1,020.7^{\mathrm{a}}$ & \\
\hline 2001 & 15.1 & $53.9 \%$ & 8.7 & $51.1 \%$ & 418.0 & $41.0 \%$ \\
\hline 2002 & 9.6 & $34.3 \%$ & 0 & 0 & 277.0 & $27.1 \%$ \\
\hline 2003 & 22.0 & $78.6 \%$ & 16.4 & $96.4 \%$ & 844.0 & $82.7 \%$ \\
\hline
\end{tabular}

"Average of 1971-2000 period.

a Lentil production started in early 1990 s in Kindersley.

Table 3: Impact of 2001-2003 droughts on agricultural yield in Eldon (RM No. 471) [7].

\begin{tabular}{|c|c|c|c|c|c|c|}
\hline \multirow{2}{*}{ Year } & \multicolumn{2}{|c|}{ Canola } & \multicolumn{2}{c|}{ Spring Wheat } & \multicolumn{2}{c|}{ Peas } \\
\cline { 2 - 7 } & $\begin{array}{c}\text { Yield } \\
\text { (bu/acre) }\end{array}$ & $\begin{array}{c}\text { \%o of } \\
\text { Historical } \\
\text { Average }\end{array}$ & $\begin{array}{c}\text { Yield } \\
\text { (bu/acre) }\end{array}$ & $\begin{array}{c}\text { \% of } \\
\text { Historical } \\
\text { Average }\end{array}$ & $\begin{array}{c}\text { Yield } \\
\text { (bu/acre) }\end{array}$ & $\begin{array}{c}\text { \%o of } \\
\text { Historical } \\
\text { Average }\end{array}$ \\
\hline Historical $^{*}$ & 24.2 & & 29.5 & & 28.6 & \\
\hline 2001 & 24.6 & $101.7 \%$ & 30.7 & $104.1 \%$ & 30.2 & $105.6 \%$ \\
\hline 2002 & 16.9 & $69.8 \%$ & 8.7 & $29.5 \%$ & 6.5 & $22.7 \%$ \\
\hline 2003 & 14.4 & $59.5 \%$ & 17.8 & $60.3 \%$ & 21.9 & $76.6 \%$ \\
\hline
\end{tabular}

Average of 1971-2000 period. 


\subsection{Effects on livestock}

Livestock production was also affected by droughts through poor pasture growth. Much of the western part of Saskatchewan (including the study communities) faced poor pasture growth (including other conditions) (Figure 5). This reduced carrying capacity of pastures, resulting in extra cost of feeding livestock. Reduced crop yields and increased cost of feeding livestock had serious effects on farm income in both the communities.

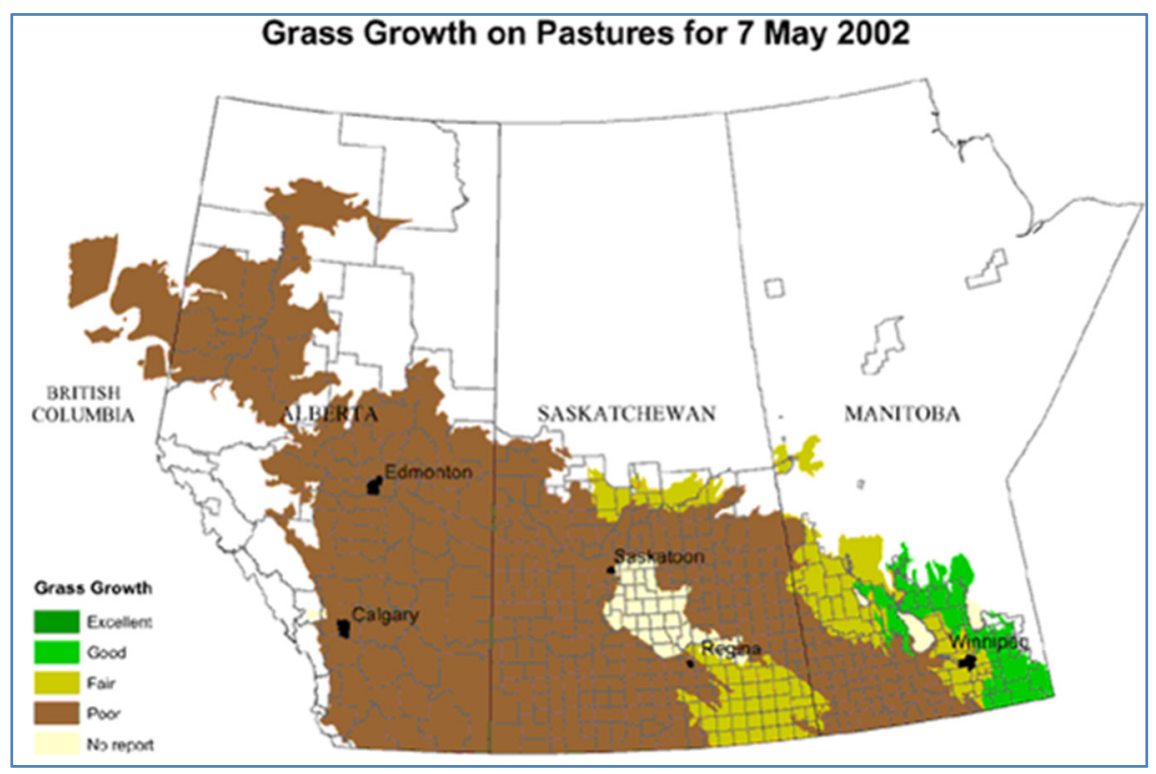

Figure 5: Pasture growth in the Prairie Provinces in 2002 [8].

Dugouts, or constructed ponds, are a source of water supply for farms and their livestock. During June to October, 2002 dugouts were completely dry in the Kindersley area and one quarter full to dry in the Maidstone area [9].

\subsection{Effect on water supply}

Drought did not impact the town of Kindersley's water supply during 2001-2003 because the main source of water is a pipeline from the South Saskatchewan River. However, in Maidstone the water level in the Maidstone Lake became low due to the 2002 drought. As a result, town of Maidstone decided to build a pipeline for underground water from the nearby village of Waseca [5].

\section{Adaptation strategies adopted in response to drought}

Adaptive capacity assessment was undertaken through the lens of the "determinants of adaptive capacity". In this study, adaptive capacity was analyzed 
in terms of five types of capital resources that assist producers to adapt under drought conditions: natural, technological, financial, institutional, and social capitals [5].

\subsection{Natural capital}

The Kindersley area's local surface water sources have proven to be inadequate for supplying water for the whole town. In addition, the town's groundwater is low in quality. The town of Kindersley and the neighboring community of Eston constructed a pipeline to the South Saskatchewan River (SSR) in 1964. The Maidstone study area is different from the Kindersley area given its far less frequent experience of severe drought. In fact, the drought of 2002 was the first serious drought episode producers had experienced in their farming career [5].

\subsection{Technological capital and infrastructure}

Dryland farmers in the Kindersley area have embraced conservation tillage (minimum tillage or zero tillage) technology following the severe droughts of the late 1980s. Minimum tillage is a farming practice of direct seeding without turning the soil, which helps to conserve soil moisture. The majority $(78 \%)$ of farmers in the Kindersley area have adopted minimum tillage. The practice of summerfallowing (a practice of leaving land untilled for one year in order to save moisture for the next period crop) has decreased in the study areas. The respondents $(13 \%)$ who still practice summerfallowing reported an average yield during the drought of 2001-2002, whereas farmers practicing minimum tillage reported below average yields. The advances in farm technology associated with minimum tillage have been widely adopted by producers $(90 \%)$ in the Maidstone area. Water supply infrastructure for the Maidstone was redeveloped in response to the drought of 2002 .

\subsection{Economic/financial capital}

Availability of financial resources is an important determinant of adaptive capacity. Agricultural producers in the Kindersley area have been impacted by the long-term cost-price squeeze in agriculture, in addition to recurrent droughts. This, according to the majority of the farmers has resulted in a general fall in their financial resources. This has resulted in less help for the young farmers starting into agriculture, a trend that was common in earlier periods.

In response to droughts and market uncertainty, farmers have diversified into a variety of agricultural products. In some cases they have increased value-added activities on the farm, as well as diversified their income through non-farm employment and entrepreneurial activities. This diversification has provided the cushion for farmers in bad farming years.

Crop diversification in the Kindersley and Maidstone areas was accomplished through replacement of traditional cereal crops (such as spring wheat, oats and barley) by a variety of new crops, such as lentils, peas, and canola. The change is 
prompted by two factors: (1) drought tolerance; and (2) high demand in international markets.

Availability of off-farm jobs provides another source of income in both Kindersley and Maidstone communities. More than $60 \%$ of respondents reported off-farm jobs contributing nearly $50 \%$ to their family income. In the majority of cases, women are working in the service industry, such as school, library, agricultural companies and the hospitality industry, in order to support family income. Most men are seasonal workers; a majority of them are employed with the oil and gas companies during winter period, while others are engaged in snow removal and driving trucks.

The mixed farmers in the area do not have time to engage in off-farm jobs. According to them, keeping cattle is a full time job. Mixed farming is type of income diversification for them. In the Kindersley area, the 2001-2002 droughts and the occurrence of BSE forced many farmers to quit livestock production. During this period, these farmers reported dependence on sales of crop products and selling hay. According to these farmers, it is more economical and less laborious for them to sell hay instead of feeding it to animals.

The oil and gas sector also contributes to the economic diversification for the town of Kindersley. According to some respondents, the town's prospects over the past few decades as an agricultural service hub would probably not have been as bright as they have been due to oil and gas activity.

Because of an already tight economic situation resulting from the first year of the 2001-2002 (for Kindersley and 2001-2003 for Maidstone) drought, many farmers were not able to make payments on their loans. As a result, farmers had to request banks to consolidate their loans or to sell their machinery to pay off debts. In bad years some farmers were not able to upgrade their machinery. They had to change their operations to limit equipment use, which makes their operation less productive.

\subsection{Institutional capital}

Historically, government institutions have provided safety nets to offset the negative socioeconomic impacts to the agricultural sector from extreme climatic events [10]. Institutions are important vehicles to adapt to both current and future droughts. In Canada, drought risk management programs have been initiated by federal and provincial governments.

Institutional support can be classified into two broad categories: Educational programs, and Business Risk Management (BRM) programs. Educational programs aim to transfer technical skills to farmers, which help them to operate their farms successfully. BRM Programs are offered by federal and provincial government to assist farmers in case of production loss by climatic and nonclimatic hazards. The BRM program includes four different types of programs: (1) Agri-Stability, (2) Agri-Invest, (3) Crop Insurance, and (4) Agri-Recovery Program. The main goal of all these programs is to help farmers gain financial stability during periods of declining farm incomes [12]. The majority of the respondents in the Kindersley area participated in BRM, whereas, less than 50\% respondents in Maidstone area made use of these programs. 
Of the four programs in the BRM category, the Agri-Stability Program is the most relevant one in the context of hazards. Farmers, who participate in this program, receive payment when their current year production margin falls below $85 \%$ of their reference margin level [12].

Crop Insurance and Agri-Stability Programs were designed to work together. For example, farmers who intend to get a benefit from Agri-Stability need to participate in the Crop Insurance Program. The Crop Insurance Program has the potential to provide income stability to farmers when climatic and non-climatic hazards impact their income.

Given the importance of BRM Programs, respondents were asked about their satisfaction level with these programs. Most of the respondents in the two communities suggested that the Agri-Stability program has many shortfalls (Figure 6). These shortfalls included: complexity, predictability, timeline issues, and additional financial burden. Complexity of the program was identified in several features of the program - conceptual as well as in terms of its implementation. Structural adjustment (formula for calculation of Agri-Stability benefits payment) method of the Agri-Stability program was a concern for many respondents as the current method of margin calculation penalizes diversified farms.

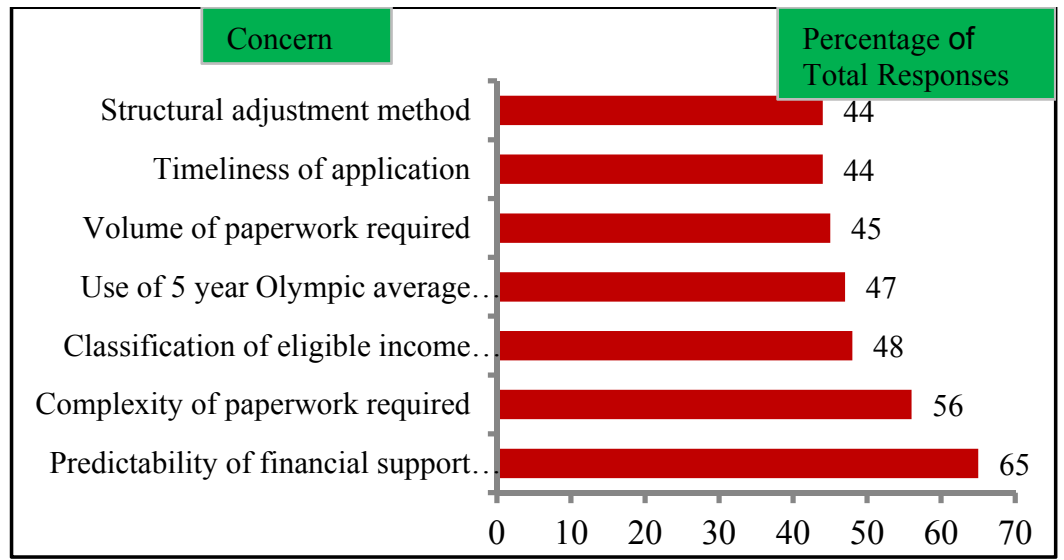

Figure 6: Respondents' concerns about Agri-Stability program in the Kindersley and Maidstone communities [5].

In addition, several other problems were noted about the Agri-Stability Program. (1) The delayed timing of receiving benefits from Agri-Stability is a concern for many respondents in the study area. (2) Some respondents mentioned poor customer services offered by the program. (3) This program does not work for mixed farmers, as they may face significant losses in crop production, but since the program is based on total income (where losses from crops are compensated by gains in livestock income), there may be no pay out from the program.

Agri-Recovery is a disaster relief program, which aims at providing "a rapid financial response to assist with immediate recovery from a disaster situation 
enabling short-term actions to minimize/contain the impacts of the disaster on producers". A vast majority (64\%) of the respondents criticized the delays in receiving assistance under the program.

Crop Insurance is a federal-provincial cost shared program, where the producers only pay $40 \%$ of the premium, while the remaining $60 \%$ is shared between the federal and provincial governments. Producers can select coverage at various levels. In Kindersley, a majority of the respondents carry crop insurance; however, many of them were not satisfied with the program (Table 4). The main concerns were high premiums and a low guarantee for loss coverage. In fact, in Kindersley during 2001-2003 multi-year drought, crop insurance did not provide any compensation.

Table 4: Respondents concerns regarding Crop Insurance.

\begin{tabular}{|l|c|c|}
\hline \multirow{2}{*}{ Responses } & \multicolumn{2}{|c|}{ Study Area } \\
\cline { 2 - 3 } & Kindersley & Maidstone \\
\hline Not suitable for multi-year droughts & $96 \%$ & NA \\
\hline Low coverage high premiums & $88 \%$ & $89 \%$ \\
\hline Early deadlines to apply & $45 \%$ & NA \\
\hline Removal of spot coverage (Hail Insurance) & $10 \%$ & $55 \%$ \\
\hline
\end{tabular}

Respondents suggested that agricultural risk management plans in Saskatchewan need continuous review according to climatic variability of the province. For example, in the case of flood of spring 2011 in Manitoba and Saskatchewan [12], farmers could not decide the size of their cultivated area without the knowledge of forthcoming climate. This suggests that eligibility criteria for the Crop Insurance need to be reviewed in response to stakeholders needs.

While the relationship of area residents with senior government institutions is strained, there are thriving local institutional networks and prairie-wide producer organizations. Indeed, the Southwest Drought Committee, created by local producers and municipal governments in response to previous drought conditions, contributed to the creation of two of the more popular senior government responses to drought: (1) Farm and Ranch Water Infrastructure Program, which assists producers with the development of community wells, shallow bury pipelines and dugouts; and (2) Tax Deferral Program, that allows cattle producers, who sell off breeding stock due to drought, to forego paying tax on the sale of cows, enabling them to use the full amount of sale proceeds to purchase replacement animals when the drought abates [5].

\subsection{Social capital}

Social capital in the Kindersley area included informal networks, such as church groups, youth and cultural group, and recreational and sport facilities typical of other communities. However, in the farming community, many respondents noted the deterioration of social capital. This decline was attributed to expansion of farm size resulting in fewer owners. 
The Kindersley area has a Farm Club which has a mandate to share technological information, but only a few respondents were members. Respondents stated that their increasing reliance on external institutions, such as seed and chemical companies and financial organizations, has affected their local links. Maidstone is home to many community-based service clubs, such as the Kinsmen and the Canadian Legion, which are slowly fading out due to fewer young people in the town and their engagement in off-farm jobs. Respondents in the Maidstone area reported a lack of enthusiasm for collective action among farmers.

\section{Vulnerability of communities}

Recent multiyear droughts have highlighted the continuous vulnerability of the Prairie Provinces and the possibility for reoccurrence in the future [13]. A majority $(83 \%)$ of the farmers claimed that two consecutive years of drought was the threshold for withstanding drought impacts; any longer droughts would create problems for the viability of many production units. Most producers believe that following two years of drought, neither they nor their neighbors could remain solvent. The two to three year drought survival window assumes that the current suite of government risk management programs, commodity price levels and input cost regimes remains relatively constant. The conclusion one can draw is that without a massive injection of government support and relief from debt obligations, three years of severe drought would threaten the continued viability of agriculture in the study areas.

In terms of role of institutions, in building adaptive capacity of producers, Prairie Farm Rehabilitation Administration (PFRA) of AAFC has developed a website called "drought watch" to inform farmers about growing season's weather conditions [12], although it does have any predictions of future drought-like conditions. Misinterpretation of these data is possible. Only (29\%) of the respondents indicated the usage of the AAFC website for their farm activities planning. The majority of respondents reported distrust on the information provided on this website with respect to moisture and precipitation predictions [5].

The PFRA has a long history of building adaptive capacity to droughts in Prairies. The PFRA has provided technical and financial help to build the water resources on farms to promote beneficial farm management practices. Many respondents stated that the PFRA has played an important role in providing the technical and financial support for the construction of dugouts and managing community pastures. The Saskatchewan Ministry of Agriculture extension staff is another institutional resource for local farmers to access information on improved farming practices.

\section{Effectiveness of government policy measures}

Although some of the government programs are effective in enhancing adaptive actions, many others are not effective. Respondents noted a change of policies and programs with a change in political parties created more uncertainties for 
producers regarding the government programs. According to one respondent, Canada still lacks the long-term policies and risk management efforts to deal with extreme climatic events, such as droughts. In fact, drought research in Canada has been fragmented and often carried out in response to severe drought occurrence.

Despite the fact that women are playing a major role in maintaining farm sustainability or in adaptation to climatic variability, very few policies or programs are geared towards farm women in Canada. Furthermore, such programs were eliminated through the 1990s. This increased the vulnerability of women for climate change and increased the pressure on women's labor capacity to meet with the challenges of climatic variability.

\section{Future climate related risks for study communities}

Future climatic risk projections for the Maidstone and Kindersley areas were identified for the periods ending in the 2080s. The future possible increases in temperature and insignificant precipitation increases in the summer months for the study areas could be problematic for the agriculture sector. Farming in the study areas depends on the timely rains and suitable temperatures. Deviations from normal temperatures could negatively impact crop production in the study areas.

Some study respondents indicated some degree of disbelief of the projections of climate change and their foreseen impacts on the local communities. Communities and individuals take proactive measures only when they perceive risk. If the communities are not considering drought as a threat, then chances of taking proactive adaptive measures are very low. Creation of this awareness is a prerequisite for any proactive planning. More research is needed to explore the reasons for lack of awareness and to find different ways to improve public awareness. This knowledge would lead to more effective adaptive measures to deal with such climatic extremes.

\section{Summary}

Drought has caused significant financial and other hardships for agriculture and livestock producers in rural communities in Saskatchewan. Institutions have played a major role in helping producers in the hard times, and in building their capacity to deal with climatic events. However, respondents from the selected rural study areas identified many shortfalls in the available business risk management programs (BRMP).

Given the spatial and temporal variability of droughts, as demonstrated here, more attention and action need to be given to local drought patterns and development of adaptive measures. The manner in which projected climate variability and change will affect local communities has not been well studied in Canada. The issue of climate change and its impact on local communities is complex and fraught with uncertainty. As bio-physical, economic and social characteristics of a given community and its environment all contribute to the resilience or vulnerability, it is crucial to understand them in an integrated manner at the local scale. 


\section{References}

[1] Environment Canada (2015). Canadian Climate Normals 1981 to 2010 for Kindersley and Waseca. Available 3 February 2015 at http://climate.weather.gc.ca/climate_normals/results_1981_2010_e.html

[2] Statistics Canada. 2014. Population of Kindersley. Accessed on January 24 2015 at $<$ http://www12.statcan.gc.ca/census-recensement/2011/dp-pd/prof/ details/page.cfm?Lang $=\mathrm{E} \& \mathrm{Geo} 1=\mathrm{POPC} \&$ Code $1=0413 \&$ Geo $2=\mathrm{PR} \&$ Code $2=47 \&$ Data $=$ Count $\&$ SearchText=Kindersley $\&$ SearchType=Begins\&Searc $\mathrm{hPR}=01 \& \mathrm{~B} 1=\mathrm{All} \&$ Custom $=\& \mathrm{TABID}=1>$

[3] Statistics Canada. 2014. Population of Maidstone. Accessed on January 24 2015 at $<$ http://www12.statcan.gc.ca/census-recensement/2011/dp-pd/prof/ details/page.cfm?Lang $=\mathrm{E} \&$ Geo $1=\mathrm{CSD} \&$ Code $1=4717018 \& \mathrm{Geo} 2=\mathrm{PR} \& \mathrm{Co}$ de $2=47 \&$ Data $=$ Count $\&$ SearchText $=$ Maidstone $\&$ SearchType $=$ Begins $\&$ Sea $\mathrm{rchPR}=01 \& \mathrm{~B} 1=\mathrm{All} \&$ Custom $=>$

[4] Meinert, A., Bonsal, B., Wheaton, E. and Siemens, E. (2010). Capturing the Dynamics of the 1999-2005 Canadian Prairies Drought. Drought Research Initiative Workshop. Regina, SK January, 2009. Retrieved from: www.drinetwork.ca/09annual/pdf/meinart.pdf

[5] Abbasi, S. (2014). Adaptation to Drought in Saskatchewan Rural Communities: A Case Study of Kindersley and Maidstone, Saskatchewan. Thesis, Master of Environment and Sustainability, University of Saskatchewan, Saskatoon, Sk. p. 144.

[6] Wheaton, E., Wittrock, V., Kulshreshtha, S., Koshida, G., Grant, C., Chipanshi, A., and Bonsal, B. (2005). Lesson Learned from the Canadian Drought years of 2001 and 2002: Synthesis Report. Retrieved from: http://www.agr.gc.ca/pfra/drought/info/11602-46E03.pdf

[7] Saskatchewan Ministry of Agriculture. (2010). Crop Yield by Municipality. Retrieved from: http://www.agriculture.gov.sk.ca/Default.aspx?DN= 5e3d0f74-ef7a-49f5-a975-f340e11 fa394

[8] Agriculture and Agri-Food Canada, PFRA. 2003. Drought Watch Website. Accessed in 2003 at www.agr.gc.ca/pfra/drought/drmaps_e.htm

[9] Wittrock, V. (2003). Canadian Droughts of 2001 and 2002: Water Resource Conditions in Western Canada: Impacts and Adaptations. Prepared for Agriculture and Agri-Food Canada. Saskatchewan Research Council, Saskatoon, SK.

[10] Environment Canada. (2010). National Climatic Data and Information Archive. Historical data retrieved from: climate.weather.gc.ca/ climate_normals/index

[11] Wittrock, V., Koshida, G., and Wheaton, E. (2005). Adaptation Strategies for Agriculture in Canada: Preparing for the 21st Century. Invited presentation to Adapting to Climate Change in Canada 2005: Understanding Risks and Building Capacity, May 4 to 6, 2005, Montreal, Quebec. Saskatchewan Research Council (SRC) Publication No. 11927-1D05.

[12] Agriculture and Agri-Food Canada. (2012a). Business Risk Management. Retrieved from http://www.agr.gc.ca/eng/aboutus/keydepartments 
62 Ravage of the Planet IV

[13] Sauchyn, D. and Kulshreshtha, S. (2008). Prairies. pp. 275-328 in D. Lemmen, F. J. Warren, J. Lacroix and E. Bush (eds.), From impacts to Adaptation, Canada in a Changing Climate. Ottawa: Government of Canada. 